Translocation equilibrée $t(2 ; 13)(\mathrm{q} 32 ; \mathrm{q} 33)$ familiale et trisomie 2q partielle. Ann Genet (Paris) 1973;16:255-8.

19 Neidich J, Zackai E, Avonson M, Emanual B. Deletion of 2p: a cytogenetic and clinical update. Am J Med Genet 1987;27: 107-10.

20 Penchaszadeh VB, Dowling PK, Davis JG, Schmidt R, Wapnir RA. Interstitial deletion of chromosome 2(p23p25). Am J Med Genet 1987;27:701-6.

${ }^{21}$ Fryns JP, De Waele P, Van Den Berghe H. Interstitial deletion of the short arm of chromosome 2 in a moderately mentally retarded boy without gross clinical stigmata. Hum Genet 1979;51:123-5.

Correspondence to Dr $\mathrm{J}$ Allanson, Division of Genetics, Children's Hospital of Eastern Ontario, 401 Smyth Road, Ottawa, Ontario K1H 8LI, Canada.

\title{
Partial monosomy $3 q$ in a boy with short stature, developmental delay, and mild dysmorphic features
}

\author{
L A BRUETON, J C K BARBER, S M HUSON, AND R M WINTER \\ Kennedy Galton Centre, Clinical Research Centre, Northwick Park Hospital, Harrow, Middlesex HAI $3 U$ UJ.
}

SUMMARY We describe the clinical and cytogenetic findings in a boy with an unbalanced karyotype involving monosomy for 3q27-q29. He does not resemble other reported cases of $\operatorname{del}(3 q)$. Deletions of the long arm of chromosome 3 are extremely rare, having been reported in five cases, only two of which had terminal $3 q$ deletions.

\section{Case report}

The proband, an eight year old male, was born to

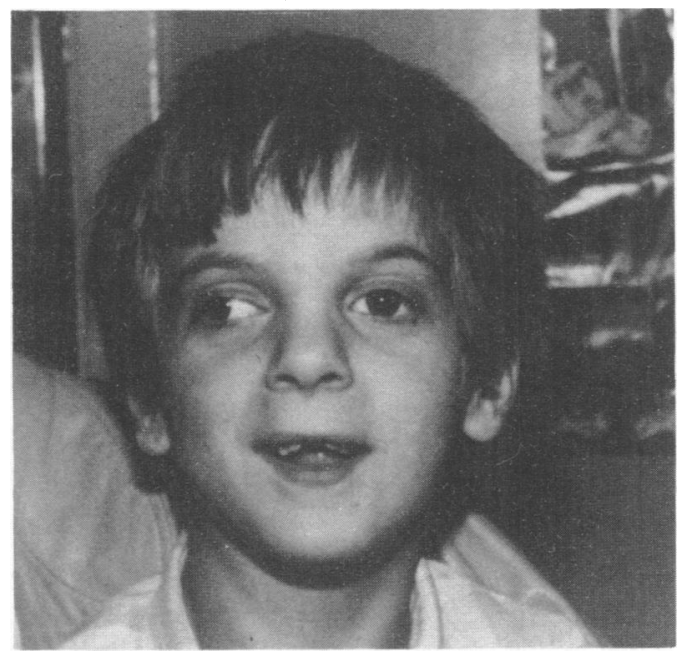

FIG 1 Facial appearance of the proband at eight years.

Received for publication 18 May 1989. Accepted for publication 1 June 1989. healthy, non-consanguineous parents. The family history was negative and there is a healthy brother and sister. The pregnancy was uneventful and the child was born at term after a normal delivery, weighing $2610 \mathrm{~g}$. He was a floppy baby and subsequent development was slow; he first walked at two and a half years.

He was referred to the Genetics Clinic at eight years of age for assessment. At this stage his length
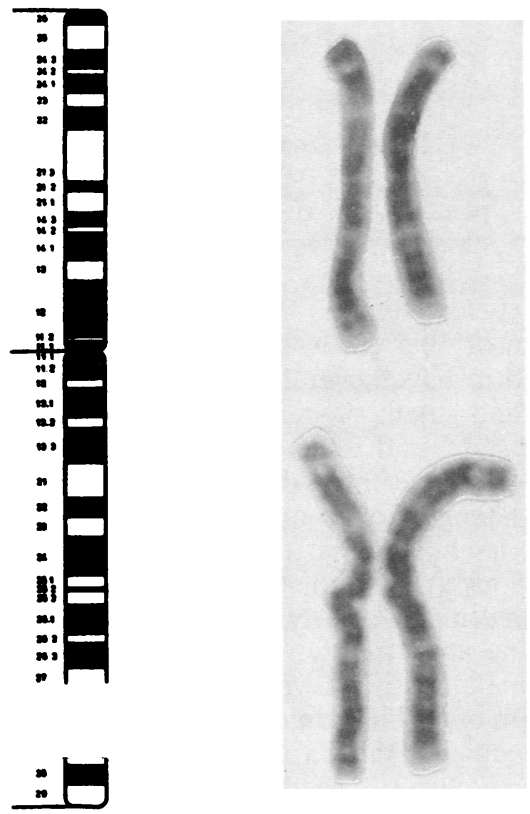

FIG $2 G$ banded partial karyotypes of the proband with the deleted chromosome on the right. The idiogram of chromosome 3 illustrates the breakpoint at 3q27. 
TABLE Cytogenetic and clinical findings in patients with terminal $3 q$ deletion.

\begin{tabular}{|c|c|c|c|}
\hline & $\begin{array}{l}\text { Alvarez Arratia } \\
\text { et at }\end{array}$ & $\begin{array}{l}\text { Sargent } \\
\text { et at }\end{array}$ & Present case \\
\hline $\begin{array}{l}\text { Deleted segment } \\
\text { Gestation }\end{array}$ & $3 q 28-q t e r$ & $3 q 27-q$ ter & $3 q 27-q$ ter \\
\hline $\begin{array}{l}\text { Gestation } \\
\text { Birth weight }\end{array}$ & $\begin{array}{l}40 \text { weeks } \\
1700 \mathrm{~g}\end{array}$ & $\begin{array}{l}37 \text { weeks } \\
3170 \mathrm{~g}\end{array}$ & $\begin{array}{l}40 \text { weeks } \\
2610 \mathrm{~g}\end{array}$ \\
\hline Failure to thrive & + & + & - \\
\hline Short stature & + & - & + \\
\hline \multicolumn{4}{|l|}{ Developmental } \\
\hline delay & + & + & + \\
\hline Hypotonia & + & + & + \\
\hline Microcephaly & + & + & - \\
\hline Skull shape & Dolichocephaly & Trigonocephaly & Normal \\
\hline Sparse hair & + & - & - \\
\hline Synophrys & - & + & - \\
\hline Hypoplastic nails & + & - & - \\
\hline Angiomata & - & - & + \\
\hline Microphthalmia & + & - & - \\
\hline Strabismus & - & - & + Left eye \\
\hline Broad nose & + & + & + \\
\hline Telecanthus & + & + & - \\
\hline Ears & $\begin{array}{l}\text { Low set. } \\
\text { malformed }\end{array}$ & Low set & $\begin{array}{l}\text { Small. } \\
\text { posteriorly } \\
\text { rotated }\end{array}$ \\
\hline \multicolumn{3}{|l|}{ Long. smooth } & + \\
\hline Lip and palate & $\begin{array}{l}\text { Cleft lip and } \\
\text { palate }\end{array}$ & - & $\begin{array}{l}\text { High arched } \\
\text { palate }\end{array}$ \\
\hline Retromicrognathia & + & - & - \\
\hline Short neck & + & + & - \\
\hline \multicolumn{4}{|l|}{ Thoracic } \\
\hline abnormalities & $\begin{array}{l}13 \text { thoracic } \\
\text { vertebrae and } \\
\text { pairs of ribs }\end{array}$ & - & Kyphosis \\
\hline Cardiac defect & $\begin{array}{l}\text { Systolic } \\
\text { murmur. } \\
\text { cardiomegaly }\end{array}$ & $\begin{array}{l}\text { Death from } \\
\text { acute } \\
\text { pericarditis }\end{array}$ & - \\
\hline Recurrent infections & + & - & - \\
\hline CT scan & & $\begin{array}{l}\text { Cerebral atrophy, } \\
\text { absence of } \\
\text { cerebellar vermis. } \\
\text { ventricular } \\
\text { dilatation. } \\
\text { posterior fossa } \\
\text { cyst }\end{array}$ & Normal \\
\hline Survival & Died at 3 months & Died at 26 months & Alive and well \\
\hline
\end{tabular}

was $110 \mathrm{~cm}$ (below the $3 \mathrm{rd}$ centile), but his head circumference of $50.5 \mathrm{~cm}$ was on the 10 th centile. He was noted to have several dysmorphic features (fig 1) including small, posteriorly rotated ears, a high arched palate, and a smooth philtrum. He had a squint in his left eye, mild thoracic kyphosis, and a resolving haemangioma on his thoracic spine (a capillary haemangioma on each eyelid had resolved previously). He had obvious developmental delay, with speech particularly retarded. A CT brain scan showed no abnormality.

Chromosome analysis showed a terminal deletion of the long arm of chromosome 3 , with a breakpoint at $3 q 27$, the unbalanced karyotype being $46, X Y$, $\operatorname{del}(3)($ pter $\rightarrow q 27:$ ) (fig 2). The parental karyotypes were normal.

An alternative interpretation is that of de novo, unbalanced translocation $46, \mathrm{XY},-3,+\operatorname{der}(3), \mathrm{t}(3 ; ?)$ (q27;?) with monosomy $3 q$ and simultaneous trisomy for a telomeric region of unknown origin.

\section{Discussion}

From the clinical viewpoint there is very little similarity between the five published cases of $3 q$ deletion $^{1-5}$ and our patient. Since the three patients with terminal $3 q$ deletion are cytogenetically similar, all being monosomic for bands q28 and q29, some phenotypic resemblance might be expected. However, the findings in common are non-specific, such as developmental delay, hypotonia, and ear abnormalities. The table summarises the clinical features of these patients. Features shared by the other two cases, ${ }^{4-5}$ but not by our patient, include microcephaly, abnormal skull shape, failure to thrive, telecanthus, and death from cardiac failure (? cause) before three years of age. The other three cases of known partial monosomy $3 \mathrm{q}$ are all interstitial deletions which overlap with one another but not the present case; the deleted segments were q22.1-q24, ${ }^{1} \mathrm{q} 23-\mathrm{q} 26,{ }^{2}$ and $\mathrm{q} 23-\mathrm{q} 25$. $^{3}$ These three had the following in common: growth retardation, developmental delay, telecanthus, a long, thin philtrum, and low set ears. The lack of phenotypic similarity, especially for more specific features such as microphthalmos, cleft lip and palate, retromicrognathia and skull shape, makes delineation of a $3 q-$ syndrome difficult. Given the paucity of reported cases of $3 q$ deletion and the clinical variability seen among these patients, recognition of a $3 q-$ phenotype remains elusive.

\section{References}

1 Williamson RA, Donlan MA, Dolan CR. Thurline HC, Harrison MT, Hall JG. Familial insertional translocation of a portion of $3 q$ into $11 \mathrm{q}$ resulting in duplication and deletion of region 3q22.1-q24 in different offspring. Am J Med Genet 1981;9:105-11.

2 Franceschini P, Cirillo Silengo M, Davi G, Bianco R, Biagioli M. Interstitial deletion of the long arm of chromosome 3 in a patient with mental retardation and congenital anomalies. Hum Genet 1983;64:97

${ }^{3}$ Martsolf JT, Ray M. Interstitial deletion of the long arm of chromosome 3. Ann Genet (Paris) 1983;26:98-9.

+ Alvarez Arratia MC, Rivera H, Möller M, Valdivia A. Vigueras A. Cantu JM. De novo del(3)(q2800). Ann Genet (Paris) 1984:27:109-11.

5 Sargent C. Burn J. Baraitser M. Pembrey ME. Trigonocephaly and the Opitz C syndrome. J Med Genet 1985:22:39-45.

Correspondence to $\mathrm{Dr}$ L A Brueton, Kennedy Galton Centre, Clinical Research Centre, Northwick Park Hospital, Watford Road, Harrow, Middlesex HA1 3UJ. 